\title{
Achene slime content in some taxa of Matricaria L. (Asteraceae)
}

\author{
HUSEYIN INCEER* \\ Karadeniz Technical University, Faculty of Science, Department of Biology, 61080 \\ Trabzon, Turkey
}

The achenes of Matricaria aurea and two varieties of M. chamomilla (var. chamomilla and var. recutita) have slime cells on the surface and they are characterized by slime envelope formation during hydration. The slime in these taxa is composed of pectins and cellulose. The slime could play important role in the distribution and colonisation of new habitats in Matricaria taxa.

Key words: achene, slime, cellulose, pectin, Matricaria

\section{Introduction}

Matricaria L. is a small genus of the tribe Anthemideae with 6 species and mostly distributed in Europe, northern Africa, Macaronesia, western, south-western and central Asia, western North America (OBERPRIELER et al. 2007). The wide range of geographical distributions and the diversity of habitats such as disturbed meadows, vacant lots, areas along roads and railroads, waste and dry areas in which Matricaria occurs may result in different adaptations to diverse environments.

The taxonomy of Matricaria is controversial and very confused. Depending on the authors, several species are classified in either Matricaria or Tripleurospermum. Therefore, they have been confused with each other, both taxonomically and nomenclaturally (JEFFREY 1979, Xifreda 1985, Kerguélen et al. 1987, Pobedimova 1995, Applequist 2002).

Achene morphology has been demonstrated to be paramount importance for the taxonomy of these genera (KYNOČLOVA 1970). Matricaria is characterized by achenes that are obovoid-oblong, circular to sligthly dorsiventrally flattened in the cross-section, with 3-5 adaxially arranged thin ribs that are sometimes furnished with longitudinal resin canals and are covered with myxogenic (slime, mucilage producing) cells mainly on their abaxial sur-

\footnotetext{
* Corresponding address, e-mail: inceer@ktu.edu.tr

Copyright $^{\circledR} 2011$ by Acta Botanica Croatica, the Faculty of Science, University of Zagreb. All rights reserved.
} 
INCEER H.

face and on the adaxial ribs (OBERPRIELER et al. 2007). However, the slime content of the achenes in the genus has not been studied so far. The aim of this study has been to examine the slime characteristics of the achenes.

\section{Materials and methods}

\section{Plant material}

The mature achenes of Matricaria aurea, M. chamomilla var. chamomilla and M. chamomilla var. recutita were collected from a native environment (Tab. 1). Plant vouchers have been deposited in the herbarium of Karedeniz Technical University Biology (KTUB) or H. Inceer collections.

Tab. 1. The origin of the materials studied

\begin{tabular}{llc}
\hline Taxon & Locality & Voucher \\
\hline $\begin{array}{l}\text { Matricaria aurea } \\
\text { (Loefl.) Sch. Bip. }\end{array}$ & $\begin{array}{l}\text { C6 Gaziantep/Sanlıurfa: Between Nizip and Birecik, Dutlu, } \\
\text { roadsides, near cultivated area, 440 m a.s.1., 08.v. 2007. }\end{array}$ & Inceer 322 \\
$\begin{array}{l}\text { M. } \text { chamomilla } \text { L.var. } \\
\text { chamomilla }\end{array}$ & $\begin{array}{l}\text { C1 Muğla: Marmaris, between Marmaris and Köyceğiz, } \\
\text { roadsides, 20 m a.s.1., 18. iv. 2007. }\end{array}$ & Inceer 305 \\
$\begin{array}{l}\text { M. chamomilla } \text { L. var. } \\
\text { recutita } \text { (L.) Fiori }\end{array}$ & C1 Muğla: Marmaris, between Kizilkaya and Fethiye, & Inceer 307 \\
\hline
\end{tabular}

\section{Slime identification by chemical reactions}

The behaviour of the fruit after wetting was observed and tests on the ability of its coat to hydrate were performed. Wetting experiments, with tap water, were performed at room temperature for 1-5 min, which was sufficient for the achenes to hydrate (KREITSCHITZ et al. 2009). Methylene blue and safranine staining were carried out to identify the slime type. The images were taken using Leica DM 4000 microscope and a Leica DFC 490 digital camera.

\section{Results}

The wetting experiments show that slime cells on the surface of the pericarp produce mucilage after which the achenes are surrounded by a slime envelope. The slime is a distinct gel-like envelope. It belongs to a cellulosic type representing a heterogenous system. Staining with methylene blue and safranine dyes demonstrate that the Matricaria slime consists of a pectinous matrix and a cellulosic skeleton (Fig. 1).

Methylene blue and safranine staining showed a characteristic pattern. Methylene blue revealed a very faint blue envelope around the achene while an orange-red coloration of the slime was obtained with safranine (Fig. 1). Staining produced almost the same colour in both pectin and cellulose. Cellulosic threads or fibrils forming a characteristic radical skeleton around the achene were clearly visible, whereas the pectin color was spread homogenously within the envelope. 


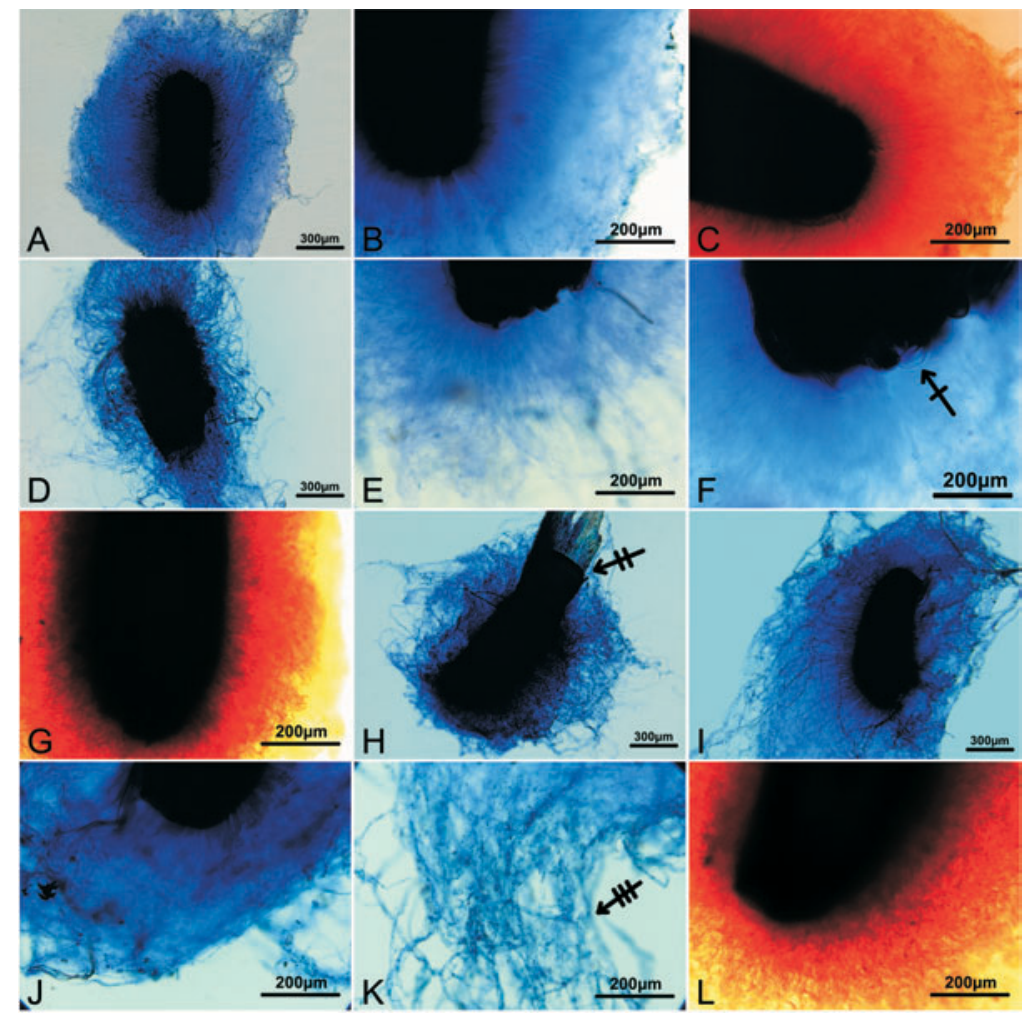

Fig. 1. Slime envelope in the achenes of Matricaria. A-B - M. aurea (methylene blue). C - M. aurea (safranine). D-F - M. chamomilla var. chamomilla (disc, methylene blue). G - M. chamomilla var. chamomilla (disc, safranine). $\mathbf{H}-$ M. chamomilla var. chamomilla (ray, methylene blue). I-K - M. chamomilla var. recutita (methylene blue). L-M. chamomilla var. recutita (safranine). Arrow with a line indicates slime cell, arrow with two lines indicates pappus, arrow with three lines indicates cellulose threads.

\section{Discussion}

The results obtained from micro-staining reactions demonstrated that the Matricaria slime is of the cellulosic type, consisting of two components i.e., pectin and cellulose. This is the first report on the slime structure of Matricaria. The staining results correspond to already published data in Artemisia and Eragrostis (BRODA 1971, GERLACH 1972, BRAUNE et al. 1975, O' Brien and MCCUlly 1981, KreitschitZ and VAllès 2007, KreitschitZ et. al. 2009, Tab. 2). In the literature, the presence of slime has been reported for many other angiosperm genera, e.g. in Brassica, Salvia, Plantago, Linum, Anthemis, Artemisia and Matricaria (MuHLethaler 1950, Young and Evans 1973, Grubert 1974, Grubert 1982, KREITSCHITZ and VALLÈS 2007). The cells producing slime could be arranged in isolated rows on the fruit surface, as in Anthemis, Artemisia and Matricaria (GRUBERT 1974). In addition, GRUBERT (1982) emphasized that proper epidermal cells of the pericarp have produced the slime in $M$. chamomilla. The present results confirm that slime cells on the surface of the pericarp produce the slime. 
INCEER H.

Tab. 2. Slime staining in Artemisia and Eragrostis species

\begin{tabular}{lllll}
\hline Staining & Target & Obtained color & Literature data & References \\
\hline $\begin{array}{llll}\text { Methylene } \\
\text { blue }\end{array}$ & Pectin & Blue & Blue & GERLACH (1972) \\
Safranine & Violet-blue & Violet, blue & $\begin{array}{l}\text { BRODA (1971 in KREITSCHITZ and } \\
\text { VALLÈS 2007) }\end{array}$ \\
& Pectin & Orange-red & $\begin{array}{l}\text { Orange-red } \\
\text { Red, } \\
\text { orange-red } \\
\text { Orange }\end{array}$ & $\begin{array}{l}\text { BRAUNE et al. (1975), O'BRIEN and } \\
\text { MCCULLY (1981), KREITSCHITZ et al. (2009) }\end{array}$ \\
& & KREITSCHITZ and VALLÈS (2007) \\
& & KREITSCHITZ et al. (2009)
\end{tabular}

The relative amount of slime is different in the studied taxa (Fig. 1). Differences in slime production can result from habitat diversity of the taxa. Such a relationship was reported in Lamiaceae (MOSQUERO et al. 2004). The achene of $M$. aurea growing in particularly dry habitats has higher amounts of slime in the envelope than the other taxa. High slime production in the achene may be an advantageous adaptive feature faciliating germination.

The functional significance of the slime in seeds and/or fruits has been reported in many works. It plays an important role in the control of germination, mostly in plants that grow in conditions of water deficiency in arid and semiarid environments, thus facilitating intake and maintenance of the water (KREITSCHITZ and VALLÈS 2007). Furthermore, it can delay germination due to impeded penetration by oxygen. Slime helps in fruit or seed dispersal and in the defence against pathogens (FAHN and Werker 1972, KorobKov 1973, Young and Evans 1973, Young and Martens 1991, HuAng and GutTerman 1999, HuAng et al. 2000). Matricaria chamomilla var. chamomilla and var. recutita, which are the most widespread taxa of the genus, occur in diverse habitats such as dry and wet environments, roadsides, field margins and ruderal places as a weed. Matricaria aurea also grows on limestone deposits, sand, saline land, flood-plain meadows with stony soil, sometimes as a weed. It is assumed that the presence of slime cells on the surface of the achenes could play an important role in the dispersal and competitive ability of these taxa.

In some particular cases, production of slime on the fruit and or seed surface may also be an adaptation to ruderal, disturbed environments (Young and Evans 1973, KREITSCHITZ and VALLÈS 2007). The presence of a slime envelope is associated with a short life cycle and facilitates the quick colonization of such places (KREITSCHITZ and VALLÈS 2007). This study confirmed this kind of adaptation in Matricaria, which is an annual. Similar adaptive mechanisms are present in many common annual weeds colonizing ruderal habitats, e.g. Lepidium flavum, L. nitidum, Plantago lanceolata, Cardaria draba (Young and Evans 1973) Arabidopsis thaliana (WESTERn et al. 2000) and Artemisia annua, A. biennis and Neopallasia pectinata (KREITSCHITZ and VALLÈs 2007).

\section{Acknowledgements}

The author thanks Dr. Faik Ahmet Ayaz, Dr. Melahat Ozcan and Murat Bal for collecting plant materials, Nursen Aksu for technical assistance, the Scientific and Technical Research 
Council of Turkey (TuBITAK, TBAG Project No. 106T162) for financial support. We thank the two anonymous referees for providing helpful suggestions to improve the manuscript.

\section{References}

ApPlequist, W. L., 2002: A reassessment of the nomenclature of Matricaria L. and Tripleurospermum Sch. Bip. (Asteraceae). Taxon 51, 757-761.

Braune, W., Leman, A., Taubert, H., 1975: Practicum of plant anatomy (In Polish). PWN, Warszawa.

BrodA, B., 1971: Methods of plant histochemistry (in Polish). PWZL, Warszawa.

FAHN, A., Werker, E., 1972: Anatomical mechanisms of seed dispersal. In: KozLOwsKi, T. T. (ed), Seed biology, I. Importance development and germination, 151-221. Academic Press, New York.

Gerlach, D., 1972: Basics of botanical microtechnique (In Polish). PWRiL, Warszawa.

GRUBERT, M., 1974: Studies on the distribution of myxospermy among seeds and fruits of Angiospermae and its ecological importance. Acta Biologica Venezuelica 8, 315-551.

GRUBERT, M., 1982: Studies on the mucilage content of myxospermatic diaspores from various angiosperm families. Plant Systematics and Evolution 141, 7-21.

HuAng, Z., GutTerman, Y., 1999: Water absorption by mucilaginous achenes of Artemisia monosperma: floating and germination as affected by salt concentrations. Israel Journal of Plant Sciences 47, 27-34.

HuAng, Z., GutTerman, Y., Hu, Z., 2000: Structure and function of mucilaginous achenes of Artemisia monosperma inhabiting the Negev desert of Israel. Israel Journal of Plant Sciences 48, 255-266.

JEFFREY, C., 1979: Note on the lectotypification of the names Cacalia L., Matricaria L. and Gnaphalium L. Taxon 28, 349-351.

Kerguélen, M., Bosc, C., LAmbÝnon, J., 1987: Données taxonomiques nomenclaturales et chrologiques pour une révision de la flore de France. Lejeunia 120, 1-264.

KreITSCHITZ, A., VALLÈs, J., 2007: Achene morphology and slime structure in some taxa of Artemisia L. and Neopallasia L. (Asteraceae). Flora 202, 570-580.

Kreitschitz, A., Tadele, Z., Gola, E. M., 2009: Slime cells on the surface of Eragrostis seeds maintain a level of moisture around the grain to enhance germination. Seed Science Research 19, 27-35.

Korobkov, A. A., 1973: Morpho-anatomical peculiarities of achene of Artemisia ssp. from north-east of the USSR. Botanicheskii Zhurnal 58, 1302-1315.

KYNOČLOVA, M., 1970: Comparative morphology of achenes of the tribe Anthemideae Cass. (Family Asteraceae) and its taxonomic significance. Preslia, 42, 33-53.

Mosquero, M. A., JuAn, R., PAstor, J., 2004: Observaciones micromorfológicas y anatómicas en núculas de Prunella L. y Cleonia L. (Lamiaceae) del suroeste de España. Acta Botanica Malacitana 29, 203-214.

Muhlethaler, K., 1950: The structure of plant slimes. Experimental Cell Research 1, 341-350.

O' Brien, T. P., McCully, M. E., 1981: The study of plant structure principles and selected methods. Termarcarphi Pty. Ltd., Melbourne, Australia. 
INCEER H.

Oberprieler, C., Vogt, R., Watson, L. E., 2007: Tribe Anthemideae Cass. In: Kadereit, J.W., JEFFREY, C. (eds.), The families and genera of vascular plants, 8, Flowering plants, Eucots, Asterales, 342-374, Springer-Verlag, Berlin.

Pobedimova, E. G., 1995: Tripleurospermum Sch. Bip. In: Shiskin, B. K., Bobrov, E. G. (eds), Flora USSR, 26, 181-213, Bishen Singh Mahendra Pal Singh, Dehra Dun, India/Koeltz Scientific Books, Koenigsten, Germany.

Western, T. L., Debra, J. S., Haughn, G. W., 2000: Differentiation of mucilage secretory cells of the Arabidopsis seed coat. Plant Physiology 122, 345-355.

XIFREDA, C. C., 1985: Sonre el nombre cientifica correcta de la manzanilla (Matricaria recutita L., Asteraceae). Darwiniana 26, 373-375.

Young, J. A., Evans, R. A., 1973: Mucilaginous seed coats. Weed Science 21, 2-54.

Young, J. A., MARTENS, E., 1991: Importance of hypocotyl hairs in germination of Artemisia seeds. Journal of Range Management 44, 438-442. 